\title{
The Lautsi Papers: \\ Multidisciplinary Reflections on Religious Symbols in the Public School Classroom
}

Edited by

Jeroen Temperman

$\frac{M \Lambda \mathrm{R} \text { I N U S }}{\text { NIJ }}$

LEIDEN • BOSTON

2012 


\title{
RESTRICTING THE PUBLIC DISPLAY OF RELIGIOUS SYMBOLS BY THE STATE ON THE GROUNDS OF HATE SPEECH?
}

\author{
Hin-Yan Liu*
}

\section{INTRODUCTION}

On 18 March 2011, a split majority of the Grand Chamber' of the European Court of Human Rights (ECtHR) reversed the unanimous decision of the Chamber ${ }^{2}$ that the mandatory display of the crucifix in public school classrooms had violated the right to education under Article 2 of Protocol 1 and the freedom of religion as guaranteed by Article 9 of the European Convention of Human Rights (ECHR). Both the Chamber and the Grand Chamber declined to address the discrimination claim under Article 14 of the ECHR.

This chapter explores the limits that may justifiably be imposed upon the manifestation of religious symbols in the public sphere by the State. As there are no stipulated requirements for the relationship between the Church and the State within the Council of Europe-and despite the general predominance of secularism within modern European States-there remains a significant degree of variation in Church-State relationships. This is especially the case with the interpretation and application of secular ideas which may be compatible with the ECHR. ${ }^{3}$ Furthermore, the acceptance of a range of Church-State relationships correlates with both the 'substantive' and the 'structural' aspects of the ECHR's margin of appreciation doctrine accorded to Member States. ${ }^{4}$ Some of these different Church-State relationships may, however, have intolerable consequences for State neutrality in denominational affairs and conflict with individual rights protected under the ECHR. Part of the perception of conflict is due to the mistaken conflation between principles of secularism and State

\footnotetext{
* Research for this chapter was generously supported by the Social Sciences and Humanities Research Council of Canada and the King's Annual Fund. I would like to thank Agnieszka Mlicka and Ming T. Lin for their insightful comments on previous drafts. This chapter expands upon ideas originally presented in "The Meaning of Religious Symbols after the Grand Chamber Judgement in Lautsi v. Italy', 6(3) Religion \& Human Rights (2011), pp. 253-257.

'Lautsi and Others $v$. Italy, 18 March 2011, European Court of Human Rights, No. 30814/06 (hereafter the 'Grand Chamber decision').

${ }^{2}$ Lautsi v. Italy, 3 November 2009, European Court of Human Rights, No. 30814/06 (hereafter the 'Chamber decision').

${ }^{3}$ Dominic Mc(roldrick, 'Religion in the European Public Square and European Public Life Crucifixes in the Classroom?', 11 (3) Human Rights Law Review (2011), pp. 453-456.

${ }^{4}$ For an influential theory on the margin of appreciation, see G. Letsas, "Two Concepts of the Margin of Appreciation', 26(4) Oxford Journal of Legal Studies (2006).
} 
neutrality. Whereas secularism may itself constitute a world-view or belief system, it is susceptible to regulation and limitation on par with other religious systems. The tolerance-based principle of State neutrality, which should be understood as a position of equidistance and impartiality, ${ }^{5}$ is unconcerned with the particular perspectives that characterise belief systems and instead dictates the requisite level of State detachment from the arena of denominational matters. ${ }^{6}$ Seen in this way, it is clear that there is the potential for Statesanctioned secularism to violate the principle of State neutrality. Secularism is not synonymous with neutrality and a State that champions secularism may in fact be taking a stance in denominational matters.

Religious symbols are, by both their nature and function, discriminatory mechanisms that serve simultaneously to ostracise those who do not share the belief system and to reinforce solidarity within the group of believers. The Regional Administrative Court in the Lautsi saga, although ultimately rejecting the discriminatory effect of the crucifix, nevertheless recognised this potential:

The logical mechanism of exclusion of the unbeliever inherent in any religious conviction, even if those concerned are not aware of it, the sole exception being Christianity ... In Christianity, even the faith of an omniscient god is secondary in relation to charity, meaning respect for one's fellow human beings ... The cross, as a symbol of Christianity, cannot therefore exclude anyone without denying itself; it even constitutes in a sense the universal sign of the acceptance of and respect for every human being as such, irrespective of any belief, religious or other, which he or she may hold. ${ }^{7}$

The Regional Administrative Court's claim that Christianity, and its symbol of the crucifix, is the sole exception to the forces of exclusion inherent within organised belief systems is questionable as a dogmatic assertion provided without sufficient grounding. Furthermore, not only is subsidiarity of the tenants of the Christian faith to universal values extremely contentious, but the message received by the perceiver need not necessarily correlate with the intended message of the sender.

Returning to the ostracising effect of religious symbols, the discriminatory role these symbols play may mark the point of departure towards greater hostility. As Susanna Mancini has suggested:

\footnotetext{
${ }^{5}$ Italian Constitutional Court Judgement No. 508 of 20 November 2000. See paras. 24 and 25 of the Chamber Judgement.

"Some commentators have pointed to the dual role of neutrality; see for instance Malcolm Evans and Peter Petkoff, 'A Separation of Convenience? The Concept of Neutrality in the Jurisprudence of the European Court of Human Rights', 36(3) Religion, State \& Society (2008).

7 Judgement No. 1110 of 17 March 2005, para. 13.4, as cited in Lautsi v. Italy, 19 March 2011, European Court of Human Rights, No. 30814/06, para. 15.
} 
Religious symbols, however, can easily turn into catalysts of aggression because they express and generate a primitive intellectual and relational level of human development-the level of blind fixations and belongings. Religious symbols unite, but at the same time they strengthen division and support the building of barriers between one's self and the other. Majorities and minorities seek shelter in religious symbols as a reflex of the increasing difficulty they experience in finding a common core of shared civic values. ${ }^{8}$

I argue here that while the manifestation of personal religious convictions should not only be tolerated, but protected by the denominationally neutral State, the discriminatory effects of religious symbols preclude their public display by the State, its organs and its officials. ${ }^{9}$ Such official displays would violate the requirement for the State to be equidistant and impartial with regard to denominational affairs, but it is not only State neutrality that is at stake. Indeed, the partisan nature of the State display of religious symbols may constitute a subtle form of intolerable official discrimination; similarly, extreme situations of ostracization may render the State display of religious symbols as hate speech towards vulnerable and minority groups.

Finally, it should also be noted at the outset that, due to the difficulty in generalising the discussion to the full range of religious symbols-the message embodied in the symbol necessarily reflects the explicit and implicit messages of the religion in question-this article will address only the symbol of the crucifix, unless stated otherwise, and the discussion will be generally limited to the Council of Europe context. It was, after all, the State display of the crucifix in Italian public school classrooms that was the point of contention in the Lautsi saga at the core of this book. I argue that there are more specific attributes of the crucifix, the Holy See, the Vatican, and the Catholic Church that may justify the curtailment of the official display of the crucifix beyond the State display of other religious symbols and in different contexts.

\section{The Quest for a Denominationally Neutral Memorial in the United States of America}

The ostracising effect of religious symbols is readily demonstrable in a campaign on the tenth anniversary of the $9 / 11$ attacks on the World Trade Centre in New York City. American Atheists filed a lawsuit to order the removal of a cross-shaped steel beam at the $9 / 11$ memorial, or in the alternative to enable

\footnotetext{
${ }^{R}$ Susanna Mancini, 'The Power of Symbols and Symbols as Power: Secularism and Religion as Guarantors of Cultural Convergence', 30(6) Cardozo Law Review (2008-2009), p. 2630.

${ }^{9}$ While the State and its organs are abstract entities whose denominational affiliation may be absolutely prohibited, the situation with restricting such manifestation of its officials necessarily requires a balancing act that takes into account the freedom of thought, conscience and religion that attaches to the person of the official.
} 
other denominational views equal representation. ${ }^{10}$ In a short blurb describing their legal challenge, the group state:

We honor the dead and respect the families, which is why we will not allow the many Christians who died get preferential representation over the many nonChristians who suffered the same fate. This was an attack against America, not Christianity, and Christianity's does not deserve special placement just because the girders look like their religious symbol."

Although it should be emphasised that the importance of religious symbols accrue especial significance when individuals are mortality salient, ${ }^{12}$ this psychological effect serves to enhance the meaning of religious symbols. In this context, the American Atheists remind us of the humble and ordinary origin of this memorial cross:

the buildings were made from girders crossing each other, and in the rubble some Christians found a pair of girders still welded that closely (not exactly, but closely enough) resemble a Christian Roman Cross. The cross has become a Christian icon. $^{13}$

The challenge brought by American Atheists illustrates the deeply embedded psychological associations engaged with the display of religious symbols especially with regard to memorials. Indeed, the Supreme Court of the United States has recently decided a similar case concerning the legality of the Mojave Memorial Cross, ${ }^{14}$ a Latin cross that was placed by the Veterans of Foreign Wars Foundation in 1934 to honour American soldiers who died in World War I, in light of the Establishment Clause of the First Amendment. ${ }^{15}$ Justice Kennedy for a narrow majority of the Supreme Court held that " $t$ ] $]$ he Constitution does not oblige government to avoid any public acknowledgment of religion's role in society", ${ }^{16}$ citing previous case law to the effect that "[a] relentless and all-pervasive attempt to exclude religion from every aspect of public

${ }_{10}$ Associated Press. 'Atheists Ask Judge to Order Removal of 9/11 Memorial Cross', The Guardian, 28 July 2011, available at <www.guardian.co.uk/world/2011/jul/28/ground-zero -cross-atheists-91 1 ? IN'TCMP $=\mathrm{SRCH}>$.

$"$ American Atheists, 'Ground Zero - An American Tragedy, Not a Christian Opportunity', available at <www.atheists.org/law/Ground_Zero >

${ }^{12}$ Kenneth E. Vail III et al., A Terror Management Analysis of the Psychological Functions of Religion' 14(1) Personality and Social Psychology Review (2010), pp. 84-94.

13 American Atheists, supra note 11.

14 Salazar v. Buono, 28 April 2010, U.S. Supreme Court (official citation not yet available at time of writing), available at <www.supremecourt.gov/opinions/09pdf/08-472.pdf $>$. See also Robert Barnes, 'Supreme Court Overturns Objection to Cross on Public Land', The Washington Post, 29 April 2010, available at <www.washingtonpost.com/wp-dyn/content/article/2010/04/28/ AR2010042801949.html>.

15 The first clause of the First Amendment, known as the Establishment Clause, provides that "Congress shall make no law respecting an establishment of religion".

is Salazar v. Buono, supra note 14, at 15 of Justice Kennedy's majority Judgement. 
life could itself become inconsistent with the Constitution". ${ }^{17}$ The tension surrounding the contentious meaning of the Mojave Memorial Cross is, however, readily illustrated. Justice Kennedy for the majority considered that "[h]ere, one Latin cross in the desert evokes far more than religion. It evokes thousands of small crosses in foreign fields marking the graves of Americans who fell in battles, battles whose tragedies are compounded if the fallen are forgotten".18 Justice Stevens wrote in his Dissenting Opinion that:

The cross is not a universal symbol of sacrifice. It is the symbol of one particular sacrifice, and that sacrifice carries deeply significant meaning for those who adhere to the Christian faith. The cross has sometimes been used, it is true, to represent the sacrifice of an individual, as when it marks the grave of a fallen soldier or recognizes a state trooper who perished in the line of duty. Even then, the cross carries a religious meaning. But the use of the cross in such circumstances is linked to, and shows respects for, the individual honoree's faith and beliefs. ${ }^{19}$

The fundamental disagreement regarding the meanings embodied within the crucifix on Italian public school classrooms closely resonates the contested meaning of the $9 / 11$ and Mojave Memorial Crosses. Indeed, in these contexts, religious beliefs can be intricately related to many pivotal moments of human lives and individual experiences, which have been empirically demonstrated to operate in order to mitigate existential terror associated with a heightened awareness of mortality. ${ }^{20}$ While the contentious display of the crucifix in Italian schoolrooms in the Lautsi saga may not raise issues of the same magnitude, they are nevertheless within the same sphere as the public display of religious symbols. It doubtlessly creates divergent effects depending upon the religious symbol, the context within which it is displayed, and both the collective and individual audience perceiving the symbol.

\section{Denominational State Neutrality in the Council of Europe}

In the introduction to this chapter (section I above), attention was drawn to the mistaken conflation between secularism and State neutrality. The relationship between secularism and State neutrality in denominational matters will be explored in this section.

${ }^{17}$ Lee v. Weisman, 24 June 1992, U.S. Supreme Court. 505 U.S. 577, at 598.

${ }^{18}$ Salazar $v$. Buono, supra note 14, at 17 of Justice Kennedy's majority Judgement. Justice Kennedy thus circumvents the more fundamental question as to whether the Mojave Cross can be suitably understood as a magnification of personal memorial crosses.

1" Salazar v. Buono, supra note 14, at 15 (fn 8) of Justice Stevens' Dissenting Judgement. This perspective is borne out by the use of the Star of David in War Memorials to mark fallen Jewish soldiers.

${ }^{20}$ Vail III et al., supra note 12, p. 87. 


\section{A. The Bare Wall of 'Aggressive Secularism' in Christian Europe}

In a recent article, Dominic McGoldrick suggested that the Chamber decision in Lautsi might have constituted 'aggressive secularism, ${ }^{21}$ an expression rooted in the upper ranks of the Catholic Church meaning "those who would indeed try to destroy our Christian heritage and culture and take God from the public square".22 The lynchpin of this presumption is essentially that, since Christianity permeates both European history and culture, the expression of Christianity in the public sphere is unproblematic. As the presumption rests upon the pre-existing Christian nature of Europe, any subsequent removal of Christian elements from the public sphere is seen, from this perspective, as the triumph of 'aggressive secularism' rather than an assertion of State neutrality through equidistance and impartiality in denominational affairs.

The Concurring Opinion of Judge Bonello at the Grand Chamber is the prime and vocal example of this strand of objection to the removal of the crucifix, where the bare wall of the public school classroom would be evidence of 'aggressive secularism' winning against the status quo of the crucifix:

Seen in the light of the historical roots of the presence of the crucifix in Italian schools, removing it from where it has quietly and passively been for centuries, would hardly have been a manifestation of neutrality by the State. Its removal would have been a positive and aggressive espousal of agnosticism or of secularism - and consequently anything but neutral. Keeping a symbol where it has always been is no act of intolerance by believers or cultural traditionalists. Dislodging it would be an act of intolerance by agnostics and secularists. ${ }^{23}$

Accusing the ECtHR of being an accomplice to "a major act of cultural vandalism", ${ }^{24}$ Judge Bonello forcefully asserted the status quo of the crucifix's position on the classroom wall both in terms of Article 9 and Article 2 of Protocol 1. In terms of religious rights, the Opinion stated perhaps paradoxically that "[f]reedom of religion is not secularism ... In Europe, secularism in optional, freedom of religion is not". 25 "The Opinion is to be welcomed insofar as it opens the debate by advocating the reconsideration of the requirements of freedom of religion and departs from the dogmatic allegiance to secularism. It is, however, unclear what principle of secularism Judge Bonello finds objectionable.

21 McGoldrick, supra note 3, p. 463.

22 Riazat Brown, 'Cardinal Keith O'Brien Warns of Threat from "Aggressive Secularism", The Guardian, 24 April 2011, available at <http://www.guardian.co.uk/world/2011/apr/24/ cardinal-keith-obrien-aggressive-secularity? INTCMP=SRCH >. See also Riazat Brown, 'Public Life Cannot be "God-free", Says Cardinal,' The Guardian, 8 May 2008, available at <http://www .guardian.co.uk/world/2008/may/08/catholicism.religion?INTCMP=ILCNETTXT3487>.

${ }^{23}$ Para. 2.10 of Judge Bonello's Concurring Opinion.

24 lbid., para. 1.4.

25 Ibid., para. 2.5 (emphasis in original). 
With regard to the right to education, Judge Bonello justifies its presence upon balancing competing horizontal rights as well as the silence of the symbol. ${ }^{26}$ The first point, which is framed in balancing the competing rights of one against twenty-nine, is misconstrued. It presupposes the unified support of the crucifix by all of the other pupils and parents. Although this is clearly a possibility, this has neither been conclusively established nor does it take into account the requirement of State neutrality regardless of the assumed majoritarian position. The second point, addressed in greater detail below, relates to the purported silence of the crucifix as "a mute object". ${ }^{27}$ Judge Bonello's adamant defence of the presence of the crucifix, however, belies his claim; after all, why come to the staunch defence of a meaningless object on a schoolroom wall? Furthermore, it is difficult to see how 'aggressive secularism' may be levelled against 'a mute object' and how the bare wall behind can evince "a positive and aggressive espousal of agnosticism or of secularism". Thus, rather than dwell on the idea of 'aggressive secularism' voiced by adherents to the Church, more mileage may be gained through the analysis of the requirement of State neutrality.

\section{B. The Requirements of State Neutrality in Denominational Affairs}

In the context of public education, Jeroen Temperman suggests two bases upon which State neutrality should rest. ${ }^{28}$ The primary requirement arises from the compulsory nature of education that mandates individuals to be present on the premises regardless of consent, and relatedly, to foster a critical approach to belief systems. ${ }^{29}$ The second requirement arises from the need to provide adequate education to all children, which necessarily must take into account both the freedom of religion of the children as well as the parental rights of educating children in conformity with their beliefs. ${ }^{30}$ From these criteria, it is possible that a singularly secular approach to education may also violate the requirement of State neutrality. This would be due to the primacy accorded to the secular world-view which would take precedence over competing religious perspectives. It does not follow, however, that the bare classroom wall bearing the imprint of the recently-removed crucifix would necessarily reflect the victory over secularism. Instead, the bare wall can be

${ }^{26}$ Ibid., paras. 3.1-3.6.

27 Ibid., para. 3.4.

${ }^{28}$ Jeroen Temperman, 'State Neutrality in Public School Education: An Analysis of the Interplay Between the Neutrality Principle, the Right to Adequate Education, Children's Right to Freedom of Religion or Belief, Parental Liberties, and the Position of Teachers. 32(4) Human Rights Quarterly (2010), p. 865.

${ }^{29}$ Ibid., 865-866.

${ }^{30}$ Ibid., 866-867. 
seen as representing the equidistance, impartiality, and even the indifference of the State in denominational matters. ${ }^{31}$

Beyond the educational context, Malcolm Evans and Peter Petkoff note that there are two strands of neutrality to be found within the jurisprudence of the ECtHR..$^{32}$ First, the State is to remain neutral in the official determination or recognition of religious activity: "The State's duty of neutrality and impartiality, as defined by the Court's case-law, is incompatible with any power on the State's part to assess the legitimacy of religious beliefs" ${ }^{33}$ Reinforcing this strand of neutrality, the Court in Masaev held that the power of the State to require the registration of religious denominations within its jurisdiction does not extend:

to sanction the individual members of an unregistered religious denomination for praying or otherwise manifesting their religious beliefs. To admit the contrary would amount to the exclusion of minority religious beliefs which are not formally registered with the State and, consequently, would amount to admitting that a State can dictate what a person must believe. ${ }^{34}$

It may be argued that the display of religious symbols by the State violates this type of neutrality, but in reverse. While Metropolitan Church of Bessarabia and Masaev concerned the censure of individuals ascribing to minority religious beliefs, the Grand Chamber's decision in Lautsi may have the effect of encouraging or rewarding those who adhere to the majoritarian religion. This is because majoritarian religious symbols, such as the crucifix, may be "used as a 'public language' of identity by the State". ${ }^{35}$ Thus, similar effects are achieved by different means. In Metropolitan Church of Bessarabia and Masaev, the State attempted to delegitimise minority religions by the refusal of the authorities to recognise the Church and by fining those who practiced a religion that was not recognised by the State respectively. Through the Grand Chamber decision in Lautsi, the delegitimation of beliefs that were not Catholic is expressed in a more subtle manner; by encouraging children toward Catholicism. The corrosive effect upon State neutrality is the same whether it is pursued by the stick or the carrot respectively.

The second strand of State neutrality concerns restrictions on the manifestation of religious belief, rather than restrictions upon the religion itself, and

"This bare wall approach to State neutrality is likely to be the best approach. The obvious alternative, to display the symbols of all religious belief systems, is both likely to overlook the symbols of minority religions and conversely to suffer from spurious claims for inclusion.

${ }^{32}$ Evans and Petkoff, supra note 6, p. 214.

${ }^{33}$ Metropolitan Church of Bessarabia and Others v. Moldova, 13 December 2001, European Court of Human Rights, No. 45701/99, para. 113.

${ }^{34}$ Masaev v. Moldova, 12 May 2009, European Court of Human Rights, No. 6303/05, para. 26.

35 Susanna Mancini, 'Taking Secularism (not too) Seriously: The Italian "Crucifix Case", 1 Religion and Human Rights (2006), p. 180. 
thus comprises the bulk of this chapter. This is that the State, within certain boundaries, may restrict individual manifestation of religious beliefs. ${ }^{36}$ The prime examples in ECtHR jurisprudence are Dahlab ${ }^{37}$ and Leyla Sahin ${ }^{38}$ both of which concerned wearing the Islamic headscarf, considered as an individual manifestation of religious belief, in the pedagogical context. In Dahlab, the applicant was a primary school teacher whose claim that the requirement to remove the headscarf in the course of her professional duties violated her Article 9 rights was held inadmissible. In Leyla Sahin, the claimant was a medical student who unsuccessfully challenged the ban on wearing the headscarf at State educational institutions provided for under Turkish law. It would appear that this strand of State neutrality is both strong and robust since limitations upon the freedom to manifest one's religion or beliefs need to be prescribed by law and necessary in a democratic society serving an enumerated list of interests. ${ }^{39}$ When this strand of State neutrality is applied to the mandatory display of the crucifix in public school classrooms it should be readily clear that the State should not be manifesting its religion since it does not have Article 9 rights, which would in any case be limited in light of the aforementioned jurisprudence. ${ }^{40}$

\section{Divergence and Disagreement: The Contentious Nature of Religious Symbols}

\section{A. Secularised Religious Symbols?}

While the severe unconscious emotional influences associated with both the 9/11 and Mojave Memorial Crosses were presumably not invoked with the display of the crucifix on Italian public schoolrooms (see section II above), the difference is likely to be only in terms of magnitude.

In the Lautsi $v$. Italy saga, a core divergence of opinion between the unanimous voice of the Chamber and the fragmented opinions of the Grand Chamber revolved around the impact and meaning of the crucifix. The most fundamental disagreement concerns the impact of the crucifix as a religious symbol. The Chamber followed previous jurisprudence in Dahlab ${ }^{41}$ and held that the crucifix was a "powerful external symbol".42 'The Chamber thus

\footnotetext{
${ }^{36}$ Evans and Petkoff, supra note 6, p. 214.

${ }^{37}$ Dahlab v. Switzerland, 15 February 2001, European Court of Human Rights, No. 42393/98.

${ }^{3 *}$ Leyla Sahin v. Turkey, 10 November 2005, European Court of Human Rights, No. 44774/98.

${ }^{39}$ Article 9(2) ECHR.

10 This is a heuristic comparison for illustrative purposes only. It is not suggested here that the State is actually capable of bearing the rights guaranteed under the ECHR.

${ }^{4}$ Dahlab v. Switzerland, supra note 37.

${ }^{42}$ Para. 54 of the Lautsi Chamber Judgement (supra note 2).
} 
recognised the potential for divergent effects on pupils dependent upon their religious views or predispositions, which justified State neutrality and impartiality in denominational matters. ${ }^{43}$ The majority of the Grand Chamber, however, asserted the diametrically opposite by concluding that "a crucifix on a wall is an essentially passive symbol ... It cannot be deemed to have an influence on pupils comparable to that of didactic speech or participation in religious activities".44

Downplaying and diluting the symbolic significance of majoritarian religious symbols has been a common tactic utilised by their proponents in justifying the continued retention of such symbols in the public realm. Susanna Mancini eloquently captured this effect:

In both conflicts over majority as well as over minority symbols, courts and legislators tend to secularize the meaning of religious symbols and interpret them according to the sensitivities, prejudices, and claims of the majority. ${ }^{45}$

The underlying assumption is that, due to the religious heritage of European societies, the symbol of the crucifix has been neutralised of religious connotations when displayed in a non-religious context.

\section{B. The Crucifix: Religious or Constitutional Symbol?}

Before moving to consider how the approach of the Grand Chamber in the instant case is inconsistent with the case law of the ECtHR more broadly, it is important to address the question as to whether or not the crucifix is a religious symbol, and whether exclusively or predominantly so. Somewhat counter intuitively, this remains a hotly debated and largely unsettled question.

The Regional Administrative Court found that the meaning of the crucifix as a symbol was context-dependent; it possessed a religious meaning within a religious context or to believers of the faith while simultaneously being capable of evoking other fundamental or core values of the Italian Republic. It may be deduced from this reasoning that there are two distinct dimensions of meaning which could be ascribed to the crucifix: the lower and broader level associated with constitutional values which is available to everyone within the Italian Republic, which I will term 'inclusionary'; and the higher and narrower level of the religious meaning that can only be accessible to believers of Catholicism, which I will label 'exclusionary'. It is crucial to note the mutually-exclusive relationship between these dimensions of meaning; the symbol of the crucifix is incapable of simultaneously embodying an exclusionary religious meaning

${ }^{43}$ Para. 55 of the Lautsi Chamber Judgement (supra note 2).

${ }^{41}$ Para. 72 of the Lautsi Grand Chamber Judgement (supra note 1; emphasis added).

45 Mancini, supra note 8, p. 2631. 
and an inclusionary secular meaning. By dissecting the meanings attributed to the crucifix in this manner, and even conceding the congruence between the values of the crucifix and the Italian Constitution, the discriminatory effect of the crucifix remains discernible. This is because the religious dimension of the symbol of the crucifix remains wholly within the realm of those who believe and thus possesses an exclusionary effect against those who do not. After all, the essence of religious symbols is to denote a particular affiliation, and in doing so, differentiate from those who are members from those who are not.

This was the reasoning adopted by the Regional Administrative Court in explicitly recognised this ostracising function that religious symbols play:

In fact, religious symbols in general imply a logical exclusion mechanism, as the point of departure of any religious faith is precisely the belief in a superior entity, which is why its adherents, the faithful, see themselves by definition and by conviction as part of the truth. Consequently, and inevitably, the attitude of the believer, faced with someone who does not believe, and who is therefore implicitly opposed to the supreme being, is an attitude of exclusion. ${ }^{46}$

The ostracising function of the crucifix as a religious symbol is a manifestation of the exclusionary dimension of symbolism attributed to it, and is accessible only to believers of the faith, are difficult to rebut and inherently discriminatory. Despite the relative difficulty in opposing this interpretation, the Regional Administrative Court, however, continued by immediately carving an exclusion zone for the role of Christian symbolism:

The logical mechanism of exclusion of the unbeliever inherent in any religious conviction, even if those concerned are not aware of it, the sole exception being Christianity ... In Christianity, even the faith of an omniscient god is secondary in relation to charity, meaning respect for one's fellow human beings ... The cross, as a symbol of Christianity, cannot therefore exclude anyone without denying itself; it even constitutes in a sense the universal sign of the acceptance of and respect for every human being as such, irrespective of any belief, religious or other, which he or she may hold. ${ }^{47}$

The sustainability of the inclusionary dimension of symbolism-those that are congruent with broader Constitutional values and secular principles-hinge upon the validity of this reasoning. The Court essentially claimed that the alleged parity between the Christian religion and broader constitutional and moral values justified the interpretation of Christian symbols as those symbols are capable of embodying broader values beyond its religious meaning.

By disentangling the two divergent meanings ascribed to the symbol of the crucifix, it becomes clear that the exclusionary dimension is dominant for

\footnotetext{
${ }^{46}$ Judgement No. 1110 of 17 March 2005, para. 13.2. See para. 15 of the Lautsi Grand Chamber Judgement (supra note 1).

${ }^{47}$ Idem.
} 
three reasons. First, there is the general exclusionary nature of religious symbols examined above. Secondly, as discussed below, the crucifix is predominantly if not exclusively a religious symbol regardless of the context in which it is displayed. Thirdly, the inclusionary dimension of symbolism is a contentious hypothetical claim that strongly hinges on the acceptance that the sign of the crucifix is capable of denoting universal values in the first place. In starker terms, it may be that the inclusionary dimension is only perceptible by those who, accepting the tenants of Catholicism, are also within the exclusionary dimension. Individuals outside of the Catholic faith may therefore remain blind to the inclusionary dimensions of symbolism which purportedly encompasses them. Thus, while the exclusionary religious dimension of the crucifix is firmly established, the countervailing argument that it also possesses an inclusionary dimension is subject to debate, resulting in the discriminatory effect of the sign of the crucifix. This effect is exacerbated by the favourable predisposition toward Christian religions to the ostracization of other religions in Europe, as Susanna Mancini writes:

On the one hand, the religious significance of majority (Christian) symbols is watered down and interpreted in "cultural" terms, not as the symbols of a given religion, but rather as indicia of the historical and cultural dimensions of national identity. On the other hand, minority - and particularly Islamic - symbols are interpreted as expressions of cultural and political values and practices which are at odds with liberal and democratic ones. ${ }^{48}$

Returning to the Grand Chamber judgment, the NGO Greek Helsinki Monitor, intervening at both the Chamber and the Grand Chamber, held the position that the sign of the cross, and especially the crucifix, could only be a religious symbol: covering the perspective of both believers and non-believers, they said that to hold otherwise was not only considered as an insult to the Catholic Church, but also inconsistent with the view that adherents of other religions saw the cross as exclusively a religious symbol..$^{49}$ The Grand Chamber also considered "that the crucifix is above all a religious symbol", but continued by saying that the "question whether the crucifix is charged with any other meaning beyond its religious symbolism is not decisive at this stage of the Court's reasoning.". ${ }^{50}$ That the Grand Chamber accepts only the religious dimension of the crucifix's symbolism is stressed by its refusal to adopt a stance on possible alternative meanings as it considered the crucifix "a sign which, whether or not it is accorded in addition a secular symbolic value, undoubtedly refers to Christianity". ${ }^{51}$ At any rate, the Grand Chamber thus left the possibility that the

\footnotetext{
4* Mancini, supra note 8, p. 2631.

49 Paras. 45-46 and 50 in the respective Lautsi Judgements (supra notes 1 and 2).

5) Para. 66 of the Lautsi Grand Chamber Judgement (supra note 1).

${ }^{51}$ Ibid., para. 71.
} 
crucifix is capable of bearing alternative meanings unresolved as it immediately continued by ruling that "a crucifix on the wall is an essentially passive symbol".52

Finally, there is the question related to the possibility of other messages that are embodied within the symbol of the crucifix unrelated to its religious role, more specifically whether there is scope for it to represent secular or constitutional values. In the Italian context at least, it is clear that in constitutional terms, there is only one symbol of the Republic. As Susanna Mancini has observed:

In the first place, there is no legal or constitutional basis to argue that the crucifix is a symbol of national unity and identity. In fact, Article 12 of the Constitution unequivocally states what the symbol of Italian national unity is. According to this provision, 'The flag of the Republic is the Italian tricolor: green, white, and red, in three vertical bands of equal dimensions.' In the interpretation of the Constitutional Court, 'given the fact that the state cannot impose ideological values that are common to citizens as a whole and to each citizen individually', the national flag is a symbol which simply identifies a given state and represents the ideals which constitute the basis of popular sovereignty. ${ }^{53}$

This would seem to clear up the question insofar as the Italian constitutional context is concerned. The broader question of secular messages embodied in religious symbols remains; indeed this question is exacerbated by the imprecise nature of the message purportedly conveyed by such symbols. In other words, since religious symbols primarily convey religious messages, the result of attempting to break this nexus generates a high level of ambiguity regarding the ability of such symbols to communicate any secular messages. This in turn generates the potential for the dissociation of the message sought to be conveyed from the message that is in fact received.

Furthermore, there is the question of the perceived meanings that are ascribed to the crucifix by observers:

[The Regional Administrative Court] is also aware that some pupils attending State schools might freely and legitimately attribute to the cross values which are different again, such as the sign of an unacceptable preference for one religion in relation to others, or an infringement of individual freedom and accordingly of the secular nature of the State, or at the extreme limit a reference to temporal political control over a State religion, or the inquisition, or even a free catechism voucher tacitly distributed even to non-belicvers in an inappropriate place, or subliminal propaganda in favour of Christian creeds. Although all those points of view are respectable, they are ultimately irrelevant in the present case. ${ }^{54}$

\footnotetext{
52 Ibid., para. 72.

${ }^{53}$ Susanna Mancini, 'The Crucifix Rage: Supranational Constitutionalism Bumps against the Counter-Majoritarian Difficulty', 6 European Constitutional Law Review (2010), p. 12.

${ }^{54}$ Judgement No. 1110 of 17 March 2005, paras. 11.1, 11.6, 11.9 and 12.1. See para. 15 of the Lautsi Grand Chamber Judgement (supra note 1; emphasis added).
} 
From this, and the other paras. excerpted from Regional Administrative Court's reasoning in the Grand Chamber judgment, it is evident that some considerable effort has been expended to secularise the religious symbol of the crucifix in order to reinvent it as a cultural symbol that has been sanitised of its previous religious associations. It is necessary to make such claims because the acceptance of the inclusionary dimension of the religious symbol would act to diminish or deny the discriminatory effect of the crucifix. ${ }^{55}$

Such attempts to 'neutralise' religious symbols are, however, unsatisfactory from both the religious and the cultural perspectives. Taking aside the aforementioned objection raised in the intervention at the Grand Chamber by the Greek Helsinki Monitor that the dilution of religious meaning from the crucifix is an insult to the Catholic Church itself, ${ }^{56}$ it may be argued that any dissociation of religion from its symbol creates tension for that religion. This is because the primacy of the religious connotation associated with the crucifix restricts it from becoming a purely cultural symbol. Susanna Mancini makes this argument:

the crucifix ... does not become a purely cultural symbol but rather a "semisecular" symbol that very effectively represents the "new" and "healthy" forms of the alliance between religion and state power ... But this "cultural" or "diffused" Christianity that supposedly pervades the Constitution produces an unacceptable discriminatory effect in that non-believers are excluded from the religious meaning of the cross. ${ }^{57}$

Similarly, the assimilation of the crucifix as a cultural symbol is capable of blurring the distinction between secularism and religion which in turn generates two insidious effects: it may open the religious sphere to State interference; ${ }^{58}$ and "denies the very possibility of a clear cut distinction between the realm of faith and that of reason, and of ruling the public sphere according to the dictates of reason. ${ }^{59}$ Framed in terms of the present argument, the attempt at asserting the primacy of the inclusionary dimension falls short and remains residual at best to the exclusionary dimensions of religious symbols and generates ambiguity at the margins of religion and secularism.

Rather than embroil itself in these debates either by asserting the primacy of the cultural aspects of the symbol of the crucifix or to neutralise its religious connotations by illustrating the secular credentials of the crucifix, the Grand Chamber adopted a variant of this approach. When the majority of the Grand

ss Susanna Mancini uses this argument to account for the inclusionary aspect of religious symbols and to explain the assertion to the universality of the crucifix before powerfully rebutting it. See Mancini, supra note 8, pp. 2640-2641.

56 Paras. 45-46 and 50 in the respective Lautsi Judgements (supra notes 1 and 2).

57 Mancini, supra note 8, p. 2639.

58 McGoldrick, supra note 3, p. 480.

${ }^{59}$ Mancini, supra note 53, p. 13. 
Chamber asserted that "a crucifix on a wall is an essentially passive symbol", 60 it circumvented the question marks hanging over the cultural and secular meanings of the crucifix. Instead, the Grand Chamber was able to divert the debate by channelling it into the comparison with the effects of didactic speech.

\section{A New Concept: 'An Essentially Passive Symbol'}

By introducing the concept of 'an essentially passive symbol' the Grand Chamber is not only at odds with the ECtHR's jurisprudence but has reversed, or at the very least obfuscated, a consistent approach to religious symbols. Religious symbols were hitherto considered as 'powerful external symbols' capable of having a strong or persuasive effect upon those in its presence. For example, the ECtHR said in Dahlab:

The Court accepts that it is very difficult to assess the impact that a powerful external symbol such as the wearing of a headscarf may have on the freedom of conscience and religion of very young children. The applicant's pupils were aged between four and eight, an age at which children wonder about many things and are also more easily influenced than older pupils. In those circumstances, it cannot be denied outright that the wearing of a headscarf might have some kind of proselytising effect. ${ }^{61}$

It is consequently difficult to reconcile the 'essentially passive symbol' of the impugned crucifix in Lautsi with the 'powerful external symbol' of the contested Islamic headscarf. While the latter allegedly possessed proselytising effects which justified its restriction, the influence of the former was severely circumscribed. Where the Chamber decision followed the 'powerful external symbol' approach expounded in Dahlab, the Grand Chamber distinguished the case: the purpose of the measure prohibiting the applicant wearing the Islamic headscarf during her teaching duties was "to protect the religious beliefs of the pupils and their parents and to apply the principle of denominational neutrality in schools enshrined in domestic law" and factored in the "tender age of the children for whom the applicant was responsible". 62

It is difficult to understand why the Grand Chamber was blind to the fact that the present case cannot be distinguished from Dahlab on these two grounds. Taking the point of denominational neutrality first, no difference is presented in the Italian situation since secularism is a constitutional principle demanding equidistance and impartiality in religious matters. ${ }^{63}$ Not only is the principle of State neutrality in religious affairs a principle borne out in the

\footnotetext{
(1) Para. 72 of the Lautsi Grand Chamber Judgement (supra note 1).

61 Dahlab v. Switzerland, supra note 37.

${ }_{62}$ Para. 73 of the Lautsi Grand Chamber Judgement (supra note 1).

${ }^{63}$ Italian Constitutional Court Judgement No. 508 of 20 November 2000. See paras. 24 and 25 of the Lautsi Chamber Judgement (supra note 2).
} 
ECtHR's jurisprudence, requiring the Court to act in instances where this is violated, but there is also domestic law asserting this same principle. The second point relating to the vulnerability of young children to the influence of religious symbols also fails to differentiate the cases. It was the foundation of Ms Lautsi's claim that the crucifix exerted a pressure on minors which was accompanied by a sense of estrangement to those who did not believe. ${ }^{64}$ While it may be conceded that on the facts, Ms Lautsi's children were older, being aged eleven and thirteen, than the children under the care of Mrs Dahlab, who were aged between four and eight at the material time, there fails to be a distinction in principle. This is because the requirement to mount a crucifix on schoolroom walls is not limited to any particular age-group of pupils, but rather is a blanket obligation. The age of the children cannot be a considered as being capable of distinguishing between the situations presented in the two cases.

The Chamber acknowledged that "it is impossible not to notice crucifixes in the classrooms. In the context of public education they are necessarily perceived as an integral part of the school environment and may therefore be considered 'powerful external symbols"' ${ }^{5}$ The factual prominence of the crucifixes was not raised by the Grand Chamber so it is assumed here that the Chamber's determination in this respect stands. The Grand Chamber's assertion of the crucifix's passivity is thus questionable if it is so readily noticeable. In this context, Judge Power's Concurring Opinion conceded "that in principle, symbols (whether religious, cultural or otherwise) are carriers of meaning. They may be silent but they may, nevertheless, speak volumes without, however, doing so in a coercive or in an indoctrinating manner" ${ }^{66}$ Perhaps Judge Power's definition of passive symbols as being non-coercive may depend on the ease by which the symbol is noticeable or dominant. This is because the purpose of a symbol is to convey a specific meaning to those who observe it. A successful symbol must therefore possess two basic characteristics; a symbol must be both easily perceptible and readily identified as a symbol associated with a discrete message. It is the meaning that the symbol conveys that is capable of differentiating it from being perceived by its observers as a mere object or 'a trinket' or 'decorative feature.67 If it is accepted that a symbol automatically conveys its meaning to the observer, a passive symbol must

${ }^{64}$ Para. 32 of the Lautsi Chamber Judgement (supra note 2).

65 Para. 54 of the Lautsi Chamber Judgement (supra note 2).

s Para. 6 of Judge Power's Concurring Opinion.

${ }^{67}$ In the Concurring Opinion of Judge Bonello, he makes explicit reference is made to the crucifix as a voiceless testimonial to a historical symbol, at para. 3.3 and crucially as "a mute object" at para. 3.4. The forceful arguments employed by Judge Bonello in defence for what he accepts as a meaningless decorative feature to remain in the classroom is void of internal consistency. 
necessarily be one that is camouflaged among its surrounding; its passivity being solely derived from its imperceptibility. Thus, a symbol can only be passive insofar as it can remain unnoticed. The Chamber's pronouncement that "it is impossible not to notice the crucifix" was not contended, suggesting that the symbols were prominent and hence incapable of being passive in the classroom.

The second possibility for a symbol to be passive is for it to not convey a meaning to its observer. This may arise from two possibilities: first, while the symbol is capable of communicating a meaning to observers, that message is not understood by its witnesses; and second, that the symbol is incapable of conveying a meaning, in which case it must be recategorised as a decorative feature or as a mere object. As it is nowhere claimed in the arguments presented to either the Chamber or the Grand Chamber that the crucifix is an object, ${ }^{68}$ and considering that despite the contentious issues revolving around the meaning ascribed to the crucifix it is understood as a religious, Christian symbol, then the conclusion that the crucifix is an 'essentially passive symbol' is oxymoronic. The crucifix conveys a message which is generally capable of being understood by the observer. Drawing a parallel with language as an agreed symbolic system used for describing reality or in order to express an idea, both language and the crucifix may be considered as symbols. Again, the Grand Chamber applied Folgero ${ }^{69}$ to the effect that the presence of the crucifix cannot be equivalent to didactic speech. The unfounded assumption here may be refuted as both didactic speech and the crucifix are symbolic systems conveying a message associated with Christianity. A further objection that may be raised here concerns the role of didactic speech as a yardstick by which to measure the communicative impact of the crucifix. The effects of symbolic systems, whether auditory or visual, are difficult to measure and compare, as with any psychological aspect. Attempts to compare the influence of the crucifix with didactic speech also miss the fact that whilst didactic speech may be the upper limit of rights violation, this does not imply that lesser infringements are acceptable.

An implication arising from the introduction of the 'essentially passive symbol' concept may be divergent treatment of a symbol dependent on whether it is the State or an individual displaying the symbol and whether it represents the majority or minority religion. A religious symbol is 'essentially passive' either if it is the symbol of the majority religion or if it is displayed by the State, but will be considered a 'powerful external symbol' if it represents a minority

68 The Supreme Administrative Court had rejected the possibility that "one can even deny [the crucifix's] symbolic value having artistic value at most", instead holding that "a crucifix displayed in a classroom cannot be considered a trinket, a decorative feature, nor as an adjunct to worship" (quoted in para. 16 of the Lautsi Grand Chamber Judgement, supra note 1).

${ }_{69}$ Folgero v. Norway, 29 June 2007, European Court of Human Rights, No. 15472/02, para. 74. 
religion or if it is expressed by an individual. The effect of introducing the 'essentially passive symbol' concept is essentially to carve out an exception to the trend of proscribing religious symbols in Europe for the majority Christian religions supported by the State. In effect then, the 'essentially passive symbol' concept is a reintroduction of the concept of 'bearing Christian witness' that was juxtaposed against 'improper proselytism' in Kokkinakis. ${ }^{70}$ To reiterate, symbols bearing Christian witness are allowed because they are passive while symbols (or a lack of them in the instant case) constitute improper proselytism as they are powerful external symbols. One effect is the privileging of State and majority religious expression, usurping a human rights instrument against the very minorities they were designed to protect. This is exacerbated in instances where the State expresses a position in religious matters as the State is incapable of holding a countervailing right which is to be balanced in purely horizontal situations whereby conflicting individual rights need to be balanced. Furthermore, considering the congruence between secularism with the principles underlying the ECHR as espoused in Leyla Sahin, ${ }^{71}$ the defence of Christian values by the Grand Chamber may threaten those very principles which it is supposed to defend.

\section{The Proselytism Question}

Another related point of divergence concerned the proselytising effect of religious symbols and whether this could be considered to infringe upon the rights and freedoms of others. Under the European Convention of Human Rights, the freedom of religion has an inherent and irreconcilable tension between the individual right to manifest religious affiliation, inter alia through the display of symbols, and the appropriate limitation of such manifestation (the forum externum) which is prescribed by law and necessary in a democratic society. ${ }^{72}$ The special difficulties embodied within the display of religious symbols are aptly illustrated in the text of Article 9 itself. Article 9(1) sets forth the absolute right to freedom of thought, conscience and religion, and Article 9(2) merely provides for express limitations upon the right to manifest a religion or belief. Returning to proselytism, the initial distinction drawn in Kokkinakis established the dichotomous relationship between "bearing Christian witness' as opposed to 'improper proselytism. ${ }^{73}$ The questionable

${ }^{70}$ Kokkinakis v. Greece, 25 May 1993, European Court of Human Rights, No. 14307/88, para. 48.

7 Leyla Sahin v. Turkey, supra note 38, para. 114.

72 Article 9(2) of the ECHR provides: "Freedom to manifest one's religion or beliefs shall be subject only to such limitations as are prescribed by law and are necessary in a democratic society in the interests of public safety, for the protection of public order, health or morals, or for the protection of the rights and freedoms of others".

${ }^{73}$ Kokkinakis v. Greece, supra note 70, para. 48. 
presumption adopted by Strasbourg favouring the majority religion is readily evident, raising the spectre of direct and indirect religious discrimination within the espace juridique of the Council of Europe.

Proselytism may be understood as improper either when the target is especially vulnerable (such as children in Dahlab) ${ }^{74}$ or if there is a hierarchical relationship or the possibility of undue influence/coercion (Larissis). ${ }^{75}$ In Larissis, the Court reiterated the questionable distinction drawn in Kokkinakis:

The Court emphasises at the outset that while religious freedom is primarily a matter of individual conscience, it also implies, inter alia, freedom to 'manifest [one's] religion', including the right to try to convince one's neighbour, for example through 'teaching.' Article 9 does not, however, protect every act motivated or inspired by a religion or belief. It does not, for example, protect improper proselytism, such as the offering of material or social advantage or the application of improper pressure with a view to gaining new members for a Church.

The question for present purposes is whether the crucifix on public schoolroom walls can be considered, per Kokkinakis, as 'bearing Christian witness' or 'improper proselytism. ${ }^{\text {'6 }}$ On the one hand, the crucifix signifies the majority religion in Italy and will likely benefit from the built-in bias. On the other hand, Lautsi appears to capture both vulnerability hallmarks of improper proselytism since it concerns children in claustrophobic and hierarchical relationships of the classroom. In order to develop this argument, Larissis provides:

In this respect, the Court notes that the hierarchical structures which are a feature of life in the armed forces may colour every aspect of the relations between military personnel, making it difficult for a subordinate to rebuff the approaches of an individual of superior rank or to withdraw from a conversation initiated by him. Thus, what would in the civilian world be seen as an innocuous exchange of ideas which the recipient is free to accept or reject, may, within the confines of military life, be viewed as a form of harassment or the application of undue pressure in abuse of power. It must be emphasised that not every discussion about religion or other sensitive matters between individuals of unequal rank will fall within this category. Nonetheless, where the circumstances so require, States may be justified in taking special measures to protect the rights and freedoms of subordinate members of the armed forces. ${ }^{77}$

A factual distinction between Larissis and Lautsi is that there was active and vocal proselytism in the former that was lacking in the latter. This may be counter-balanced, however, by the particular vulnerability of minors and the

\footnotetext{
${ }_{71}^{71}$ Dahlab v. Switzerland, supra note 37.

75 Larissis and others v. Greece, 24 February 1998, European Court of Human Rights, Nos. 23372/94; 26377/94;26378/94.

76 Again, since the State is incapable of bearing ECHR rights, this argument is made by analogy only.

${ }_{77}$ Larissis and others v. Greece, supra note 75, para. 51.
} 
power of the State placed behind the religious symbol. In other words, while the mandatory public display of the crucifix may be unproblematic in situations that are open, democratic and non-coerced, its presence in the pedagogical context that is characterised by disciplinary and hierarchical relationships is inappropriate because it presupposes improper proselytism.

A different way of approaching the proselytism question may be to focus upon the reason behind and purpose for the requirement to display the crucifix on public schoolroom walls. By way of analogy, the U.S Supreme Court in Stone v. Graham ${ }^{78}$ held that a Kentucky statute that required the display of a copy of the Ten Commandments in public school classrooms violated the Establishment Clause of the First Amendment on the grounds that it served no secular legislative purpose:

Posting of religious texts on the wall serves no such educational function. If the posted copies of the Ten Commandments are to have any effect at all, it will be to induce the schoolchildren to read, meditate upon, perhaps to venerate and obey, the Commandments. However desirable this might be as a matter of private devotion, it is not a permissible state objective under the Establishment Clause. ${ }^{79}$

The purpose that is served by requiring the display of the crucifix is neither raised by the parties nor mentioned in either of the Strasbourg judgments. Thus, although the purpose of the crucifix display is uncertain, avoidance of such considerations suggest the lack of any such purpose which militates against its mandatory presence. Associated with the purpose is the consideration of the source of authority. In Lautsi the legal source ${ }^{80}$ behind the mandatory crucifix display was a royal decree of 1860 that predated the Italian Republic itself. This lapsed a decade later, only resurrected by a fascist era decree in 1922 in turn supplemented by two further royal decrees from the same era. ${ }^{81}$ The antiquated nature of these sources led the intervening NGO Associazione Nazionale del Libero Pensiero to suggest that they had since been impliedly repealed, ${ }^{82}$ and their authoritarian nature absent Parliamentary enactment was noted by the Dissenting Judges as lacking democratic legitimacy. ${ }^{83}$ Thus, although the schoolroom crucifix is a symbol of the dominant religion and as such is initially (albeit controversially) excluded from proselytism, the absence of a compelling purpose for its display is further compounded by the vulnerability of its perceivers. These factors may be enough to overcome

78 Stone v. Graham, 17 November 1980, U.S Supreme Court. 449 U.S. 39.

79 Ibid. at 42.

80 Paras. 17-25 of the Lautsi Grand Chamber Judgement (supra note 1) provide the historical background behind the requirement to display the crucifix on public schoolroom walls.

${ }^{81}$ See in particular para. 19 of the Lautsi Grand Chamber Judgement (supra note 1).

\$2 Para. 51 of the Lautsi Grand Chamber Judgement (supra note 1).

s3 Dissenting Opinion of Judge Malinverni joined by Judge Kalaydjieva, at p. 47 of the Lautsi Grand Chamber Judgement (supra note 1). 
the initial exclusion and justify the removal of the crucifix on the grounds of 'improper proselytism'.

It may therefore be possible to limit the public display of the crucifix upon its ability to communicate religious messages that infringe upon the freedom of thought, conscience and religion enshrined in Article 9. Indeed, while the communicative dimension of religious symbols has often been noted, its consideration has generally remained within the ambit of Article 9 only. This communicative nature of religious symbols may also putatively engage the freedom of expression found within Article 10, at least as a residual ground but it should be emphasised, however, that grounding such claims under Article 10 may work both to reinforce the right to manifest religious symbols as well as to justify further limitations. ${ }^{84}$

\section{Manifestation of Religion as the Freedom of Expression}

Turning to the possibility of religious symbols as a form of communicative expression that is protected under Article 10, it should be noted that while the religious dimension of the crucifix was never scrutinised, the potential for the crucifix to embody other messages or philosophies was raised. This ground was never adequately addressed, however, and leaves unexplored the potential of restricting the public display of the crucifix on other grounds.

Two points should be noted at the outset of this discussion. The first is that the freedom of expression covers two related sets of interests; those of the speaker in communicating ideas and information and those of the audience for receiving them. The bias is often placed upon the protection of the interests of the speaker that comes at the cost of neglecting the concomitant rights of the audience. The second is that religious symbols are prima facie capable of being understood as forms of expression; provided that a specific meaning may be attributed to an object it may be protected as a form of symbolic speech. ${ }^{85}$

Under the ECHR, the freedom of expression is embodied within Article 10 and while providing for absolute freedom, such as is found in Article 9, primarily has its restrictions placed upon ' $[t]$ he exercise of these freedoms, since it carries with it duties and responsibilities. ${ }^{36}$ Inherent within the freedom of

\footnotetext{
${ }^{84}$ Neither the Chamber nor the Grand Chamber expressly addressed Article 10 with relation to the public schoolroom crucifixes.

ks The idea of 'symbolic speech' arises from federal United States jurisprudence. The best example of this protection in a pedagogical context is the Supreme Court in Tinker pronouncing that the restriction of wearing black arm bands in opposition to the Vietnam War at school was unconstitutional. Tinker v. Des Moines Independent Community School District, 393 U.S. 503 (1969), p 514.

Ko Article 10(2) of the ECHR (emphasis added).
} 
expression, however, is that its exercise may be limited insofar as such limitations are prescribed by law and necessary in a democratic society. This may suggest that there will be no prima facie differences between whether the public crucifix is supported or limited upon Article 9 or Article 10 since the ECHR itself protects these freedoms in a similar manner. Such an approach is, however, erroneous since additional dimensions arise from focussing upon the communicative aspects of such display that are invisible to a purely thought, conscience and religion analysis.

Two interrelated points arise from such a focus on Article 10 in this context, both of which involve Article 17 of the ECHR in a different light to its application in Article 9. Article 17 provides for the prohibition of abuse of rights and stipulates that:

Nothing in this Convention may be interpreted as implying for any State, group or person any right to engage in any activity or perform any act aimed at the destruction of any of the rights and freedoms set forth herein or at their limitation to a greater extent than is provided for in the Convention.

In the context of Article 9, this is manifested in the restrictions against improper proselytism; the protection afforded by Article 9 cannot be invoked by one party to infringe upon the Article 9 rights of others since it is not expressly provided for in the ECHR. Aside from the discriminatory manner in which this prohibition developed in the ECtHR jurisprudence, questions of discrimination largely fall away in this context. Similarly, the prevention of the abuse of Article 9 goes only so far as to assert State impartiality and equidistance in denominational matters per Masaev and Bessarabia.

Adopting this approach from the Article 10 perspective, however, brings different elements to the fore. The question of discrimination, may for instance, be broadened beyond the consideration as to whether there is the predisposition of the State to favour one religion over another and may instead be posed in terms of State interference of the freedom to receive information and ideas. ${ }^{87}$ The emphasis placed upon the communicative dimension of the crucifix as a symbol removed of its religious connotations opens up the possibility for a rational analysis of its potential for discrimination as well as offering another substantive ground upon which the parasitic prohibition of discrimination may attach. More importantly, however, shifting the analysis towards Article 10 opens up entirely new grounds for justifying the restriction of the

${ }^{k 7}$ The ECtHR has afforded a high level of protection to the freedom to receive information and ideas inter alia by holding the State to a strong positive obligation to prevent horizontal interference that is not strictly necessary in a democratic society. See the unanimous decision of the Chamber in Khurshid Mustafa v. Sweden, 16 December 2008, European Court of Human Rights, No. 23883/06. 
public display of the crucifix unavailable under Article 9; those associated with hate speech.

In order to develop this argument, it is first necessary to consider the freedom of expression in the pedagogical context. This will be followed by a brief argument that the public display of the crucifix may be a form of discriminatory speech which should be limited due to its potential for constituting blasphemy and incitement towards religious hatred. This argument is then developed further towards a stronger and context-specific form of hate speech that is centred up the display of Catholic symbols in relation to children.

A useful point of departure regarding freedom of speech rights in the pedagogical context was provided by Justice Fortas speaking for the majority of the U.S Supreme Court in Tinker:

First Amendment rights, applied in light of the special characteristics of the school environment, are available to teachers and students. It can hardly be argued that either students or teachers shed their constitutional rights to freedom of speech or expression at the schoolhouse gate. ${ }^{88}$

It is clear that the freedom of speech, along with other constitutional rights, is applicable in the U.S. classrooms. ${ }^{89}$ Special freedom of expression considerations do, however, apply in the context of education which have focussed specifically upon the expression rights of the students and teachers. ${ }^{90}$

The protection of student expression is found in two complementary U.S. Supreme Court cases of Tinker ${ }^{91}$ and Barnette ${ }^{92}$ which protected the right to speak and the right not to speak respectively. In the former case, the Supreme Court held that school restrictions prohibiting students from wearing black armbands silently in opposition to the Vietnam War contravened the First Amendment. In the latter case Jehovah's Witnesses raised a constitutional objection to a state requirement for children in public schools to salute and pledge allegiance to the flag of the United States. Justice Jackson for a majority at the Supreme Court declared that:

If there is any fixed star in our constitutional constellation, it is that no official, high or petty, can prescribe what shall be orthodox in politics, nationalism,

${ }^{88}$ Tinker v. Des Moines Independent Community School District, supra note 85, at p. 506.

"99 "The Fourteenth Amendment, as now applied to the States, protects the citizen against the State itself and all of its creatures - Boards of Education not excepted. These have, of course, important, delicate, and highly discretionary functions, but none that they may not perform within the limits of the Bill of Rights": Justice Jackson in West Virginia State Board of Education v. Barnette 319 US 624 (1943), p. 637.

40 See generally, Eric Barendt, Freedom of Speech (New York: Oxford University Press, 2007), pp. 496-502.

${ }^{91}$ Tinker v. Des Moines Independent Community School District, supra note 85, at p. 503.

92. West Virginia State Board of Education v. Barnette, supra note 89. 
religion or other matters of opinion or force citizens to confess by word or act their faith therein. ${ }^{93}$

Although this right not to speak is not directly applicable to Lautsi, since there was no requirement to actively acknowledge the presence of the crucifix, ${ }^{94}$ it should be noted that this right to silence forms the core of ECtHR jurisprudence on Article 9 that obliges the State to guarantee the exercise of religions, faiths and beliefs in a neutral and impartial manner per Buscarini and Alexandridis. ${ }^{95}$

But there is more to the Barnette judgment than simply the incompatibility with the Constitution of being forced to declare allegiance to the flag as the declaration by Justice Jackson above alludes to. While the Grand Chamber in Lautsi appeared to draw the fine distinction between passive presence of the crucifix and active participation in religious activities or didactic speech, ${ }^{96}$ which formed the basis of its finding that its presence cannot amount to impermissible indoctrination, ${ }^{97}$ it neglected to account for the prescription of orthodoxy element inherent in the display of the crucifix in the public schoolroom. The State endorsement of the crucifix display itself can be understood as its pronouncement and preference for Catholicism specifically, or Christian religions more broadly, and should be limited upon such grounds. Furthermore, the assumed requirement that there be active participation in religious activities and didactic speech for indoctrination is questionable. It may be that such activities will engage students in a more open, critical and pluralistic manner than the silent communication devoid of debate and discussion as to its content.

\section{Restricting the Public Display of the Crucifix on the Grounds of Hate SPEEch}

The freedom of expression is not unlimited and may be restricted in order to balance competing rights and interests, and the primacy of expression is neither clear nor conclusively established in all situations. This is especially the case with hate speech, which can be loosely defined as degrading speech intended to intimidate or incite violence against certain persons or

\footnotetext{
${ }^{43}$ Idem., p. 642.

94 The Government's view was that the crucifix was a passive symbol that could not be comparable in impact to active conduct. See para. 36 of the Lautsi Grand Chamber Judgement (supra note 1 ).

95 Buscarini v. San Marino, 18 February 1999, European Court of Human Rights, No. 24645/94; and Alexandridis v. Greece, 21 February 2008, European Court of Human Rights, No. $19516 / 06$.

\% Para. 72 of the Lautsi Grand Chamber Judgement (supra note 1).

${ }^{77}$ Para. 62 of the Lautsi Grand Chamber Judgement (supra note 1).
} 
groups, ${ }^{98}$ which can have severe adverse effects upon the dignity of those targeted. Arguing in principle, Eric Barendt suggests the possibility for hate speech to "express contempt for the targeted individuals or groups; some publications ... demean human dignity and humanity itself". ${ }^{99}$ Due to the possibility of infringing upon the dignity of its victims, the curtailment of hate speech is readily justified in most jurisdictions as well as in principle. The only remaining question is the extent to which it is balanced, depending upon the particular facts of each situation.

\section{A. The Discriminatory Nature of Blasphemy and Incitement to Religious Hatred Laws}

It is instructive for the following argument to recognise the likelihood of this chapter falling foul of the old UK common law offence of blasphemous libel merely by alluding to the possibility that the sign of the crucifix may constitute a form of hate speech. It is fortunate that such claims attract less controversy in modern times to the point that this offence may have become temporarily obsolete between 1922 and 1977 due to the absence of prosecutions in this period. ${ }^{100}$ The discriminatory nature of this common law offence, which owed its origins to canon law, is blatantly evident in its exclusive coverage of Christian religions. According to Chief Justice Hale in Taylor, ${ }^{101}$ the first reported case for this offence, the specific protection of the Church of England is due to its close connection with the government. The exclusive coverage of blasphemy laws was upheld in modern times in a private prosecution concerning the publication of The Satanic Verses by Salman Rushdie. The Divisional Court affirmed that the common law offence protected only Christianity and that the offence could not be broadened to cover other religions. ${ }^{102}$

There is also evidence of an in-built prejudice towards Christianity in the ECtHR itself through two decisions related to religiously provocative films. In Otto-Preminger, ${ }^{103}$ the ECtHR considered that the seizure and forfeiture of a film considered disparaging to Christianity was justified to protect the individual right to not have religious feelings insulted within the ambit of Article 10(2). Similarly in Wingrove, ${ }^{104}$ the refusal of the Board of Film

\footnotetext{
${ }^{9 *}$ For a comparative analysis of constitutional protection for hate speech, see Hin-Yan Liu, 'The Constitutional Right to Express Hatred: A Comparative Analysis', 1(1) King's Student Law Review (2008-2009), pp. 5-21.

Barendt, supra note 90, p. 34.

100 Ibid., p. 186.

${ }^{101} R v$. Taylor [1676] I Vent 293.

${ }_{102} R$ v. Chief Metropolitan Stipendiary Magistrate, exp. Choudhury [1991] 1 QB 429.

${ }^{103}$ Otto-Preminger-Institut v. Austria, 20 September 1994, European Court of Human Rights, No. $13470 / 87$.

${ }^{104}$ Wingrove v. UK, 25 November 1996, European Court of Human Rights, No. 17419/90.
} 
Classification to allow the release of a film portraying explicit sexual fantasies of St Teresa of Avila was also upheld by the ECtHR as national authorities were permitted to prevent blasphemous insult to the public, despite this being a clear situation of prior censorship which is a form of curtailment that usually requires strong justifications. Not only was the claim that individuals have the right not to have their religious sensibilities insulted made without support, but it is also difficult to square with the jurisprudence of the ECtHR itself which stipulated that the freedom of expression includes the right to express ideas that shock and disturb. ${ }^{105}$

The purpose of pointing out these discriminatory slants favouring Christianity in Western jurisprudence is to emphasise the imperceptibility that the display of a Christian symbol may inflict injury to individuals and groups, even (or perhaps especially) in populations that are predominantly or culturally Christian. It should also be recalled that Christianity was not always as benign as it has been in modern times and that it was not necessarily characterised as a "universal sign of the acceptance of and respect for every human being". ${ }^{106}$ In this context, it is worth invoking the words of the Regional Administrative Court again:

Moreover, with the benefit of hindsight, it is easy to identify in the constant central core of Christian faith, despite the inquisition, despite anti-Semitism and despite the crusades, the principles of human dignity, tolerance and freedom, including religious freedom, and there, in the last analysis, the foundations of the secular State. ${ }^{107}$

Even if it is conceded that the crucifix is emblematic of universal respect and dignity in modernity, it has to be accepted that the historical record of Christianity has been littered with intolerance, disrespect for others and militancy as the Regional Administrative Court itself impliedly accepts. If this is the case, the crucifix is clearly capable of bearing messages that degrade individuals and groups or may be justifiably interpreted as communicating such messages. Indeed, one does not need to look far for evidence of homophobia by senior Church officials. ${ }^{108}$ Perhaps more disturbing, however, is the exhibition of institutional homophobia by the Vatican when it deployed its United Nations permanent observer status to oppose a proposed

\footnotetext{
${ }^{105}$ Barendt, supra note 90, p. 192.

106 Judgement No. 1110 of 17 March 2005, para. 13.4. See para. 15 of the Lautsi Grand Chamber Judgement (supra note 1).

107 Judgement No. 1110 of 17 March 2005, paras. 11.1, 11.6, 11.9 and 12.1. See para. 15 of the Lautsi Grand Chamber Judgement (supra note 1; emphasis added).

108 Rory Carroll and John Hooper, 'Vatican Attacked over Vardinal's Claim of Homosexuality and Paedophilia Link', The Guardian, 13 April 2010. available at <http://www.guardian.co.uk/ world/2010/apr/13/vatican-homosexuality-paedophilia-claim-condemned>.
} 
U.N. Resolution that would call on national governments to decriminalise homosexuality. ${ }^{109}$

Thus, not only does Christianity have a tarnished historical record of intolerance, degrading forms of discrimination and even violence, but this taint is carried through to the present day by the Catholic Church's continued opposition to the equal rights and recognition of homosexuals. As important as it is to underscore the Catholic homophobia, this pales in comparison to the international child abuse scandal that is of particular relevance to the situation in Lautsi.

\section{B. The Specific Context: Catholicism and the Child}

The last substantive section of this chapter will consider the specific context of children and their relationship with the Catholic Church, and will address the ramifications of the child sexual abuse scandal on the appropriateness of displaying the crucifix in public schoolrooms in which children are required by law to inhabit for long and sustained periods.

Before proceeding, it is particularly noteworthy that the Amnesty International Annual Report 2011 concluded that the "Holy See did not sufficiently comply with its international obligations relating to the protection of children", reiterating the widespread allegations of child sexual abuse and the enduring failure to address these crimes adequately; it was further noted that the Holy See had failed to submit both its second period report on the UN Convention of the Rights of the Child which was due in $1997 .{ }^{110}$ The Report noted:

Increasing evidence of widespread child sexual abuse committed by members of the clergy over the past decades, and of the enduring failure of the Catholic Church to address these crimes properly, continued to emerge in various countries. Such failures included not removing alleged perpetrators from their posts pending proper investigations, not co-operating with judicial authorities to bring them to justice and not ensuring proper reparation to victims. ${ }^{111}$

That the Holy See, the territorial counterpart to the Vatican and the Catholic Church, is given recognition at the United Nations demonstrates the preferential treatment that Catholicism enjoys on the international plane ${ }^{112}$ that

${ }^{109}$ Phillip Pullella, 'Vatican Attacked for Opposing Gay Decriminalisation', Reuters, 2 December 2008, available at <uk.reuters.com/article/2008/12/02/uk-vatican-homosexuals -idUKTRE4B13N020081202>.

110 Amnesty International, Amnesty International Annual Report 2011: The State of the World's Human Rights: Vatican', at 162-163, available at <files.amnesty.org/air11/air_2011_full -en.pdfs.

III Ibid., at 162.

112 For the history of, and a sustained argument against, the statehood claims of the Holy See, see Geoffrey Robertson, The Case of the Pope: Vatican Accountability for Human Rights Abuse (London: Penguin, 2010). chapter 6. 
mirrors that aforementioned favouritism in domestic and regional legal orders. It is clear from the Amnesty International Report that the Holy See does not take its responsibilities under the UN Convention seriously, but this is far from the end of the story.

As the child sexual abuse scandal of the Catholic Church has been well documented by Geoffrey Robertson, ${ }^{113}$ it is unnecessary to go into the full details here. It is international in scope, with settlements alone reaching Canada ${ }^{114}$ and the Netherlands ${ }^{115}$ while facts are still being established and cases compiled elsewhere. ${ }^{116}$ While its widespread nature is disconcerting, it is the institutionalised and systematic basis upon which this abuse occurred that is deeply troubling. A recent case at the High Court in the UK has affirmed the amenability of the Catholic Church to legal suit for the wrongful conduct of its priests, ${ }^{117}$ despite the unsurprising protest from a Catholic bishop. ${ }^{118}$

It is, however, the evidence that those suspected of perpetrating such abuses were not punished, but were rather sheltered by the Catholic Church that forms the basis of the present claims to institutional and systematic child sex abuse. In particular, Cardinal Ratzinger, before he became Pope Benedict XVI, had headed the Congregation for the Doctrine of the Faith (CDF) which was responsible for handling sexual abuse cases and had manifestly failed to fulfil the disciplinary function. ${ }^{119}$ The systematic footing of the Catholic Church's sexual abuse scandal is capable of elevating it to the plane of international criminal law as a crime against humanity. ${ }^{120}$ While crimes against humanity are generally associated with situations of armed conflict, the Appeals Court of

113 Ibid., see especially chapters $1-3$ (facts) and 7-10 (law).

114 Ian Austen, 'Canada: Catholic Order Settles Sexual Abuse Suit for \$17 Million', The New York Times, 6 October 2011, available at <www.nytimes.com/2011/10/07/world/americas/ canada-catholic-order-settles-sexual-abuse-suit-for-17-million.html?ref=romancatholicchurch
sexabusecases $>$.

115 The Associated Press, 'The Netherlands: New System to Compensate Abuse Victims', The New York Times, 7 November 2011, available at <www.nytimes.com/2011/11/08/world/europe/ the-netherlands-new-system-to-compensate-abuse-victims.html?ref=romancatholicchurchsex abusecases $>$.

116 Riazat Butt, 'Pope's UK Visit Prompts Increase in Sex Abuse Allegations against Church', The Guardian, 28 July 2011 , available at <www.guardian.co.uk/world/2011/jul/28/pope-visit -sex-abuse-allegations-catholic-church?INTCMP=ILCNETTXT3487>.

11 Riazat Butt, 'Catholic Church can be held Responsible for Wrongdoing by Priests', The Guardian, 8 November 2011, available at <www.guardian.co.uk/world/2011/nov/08/ catholic-church-responsible-priests-court?INTCMP=SRCH $>$.

118 Riazat Butt, 'Catholic Bishop Criticises Ruling on Church Liability for Actions of Priests', The Guardian, 15 November 2011, available at <www.guardian.co.uk/world/2011/nov/15/ catholic-bishop-liability-church-priests $>$.

119 Robertson, supra note $112, \mathrm{Ch} .8$.

120 Karen McVeigh, 'Pope Accused of Crimes Against Humanity by Victims of Sex Abuse', The Guardian, 13 September 2011, available at <www.guardian.co.uk/world/2011/sep/13/ pope-crimes-humanity-victims-abuse?INTCMP=ILCNETTXT3487>. See also Laurie Goodstein, 'Abuse Victims Ask Court to Prosecute the Vatican', The New York Times, 13 September 2011, available at <www.nytimes.com/2011/09/14/world/europe/14vatican.html>. 
the International Criminal Tribunal for the Former Yugoslavia affirmed in Tadic that such a link is not a requirement. ${ }^{121}$ Furthermore, Article 7 of the Rome Statute for the International Criminal Court provides that:

1. For the purpose of this Statute, 'crime against humanity' means any of the following acts when committed as part of a widespread or systematic attack directed against any civilian population, with knowledge of the attack:

(g) Rape, sexual slavery, enforced prostitution, forced pregnancy, enforced sterilization, or any other form of sexual violence of comparable gravity; ${ }^{122}$

The point here is not to consider the susceptibility of the Pope and other senior officials to charges of crimes against humanity, since additional barriers of jurisdiction and command responsibility will need to be satisfied. The purpose is instead to illustrate the potential for the sign of the crucifix to be linked to the child sexual abuse scandal of the Catholic Church and the possibility that the crucifix may communicate messages of degradation or intimidation to children, especially due to the widespread and global nature of this scandal. While the public display of the crucifix in the absence of children may be excluded from the context-specific objection against the display of the crucifix ${ }^{123}$ it is a precisely and directly pertinent factor in Lautsi that was ignored by the Grand Chamber.

The Supreme Court of Canada in Ross ${ }^{124}$ unanimously upheld the removal of a primary school teacher from his post who wrote anti-Semitic books and pamphlets outside of class. The Supreme Court found a rational connection between Malcolm Ross's conduct and the 'poisoned educational environment' that was the specific harm in question, ${ }^{125}$ and underlined both the pedagogical context and the character of the speech. ${ }^{126}$ It emphasised the responsibility of schools in fostering a pluralistic and tolerant society and recognised that young children may have difficulties in isolating comments made in and outside of

\footnotetext{
${ }^{121}$ Prosecutorv. Tadic Decision on the Defence Motion, 2 October 1995, Appeals Court of the International Criminal Tribunal for the Former Yugoslavia, IT-94-1-AR72-2.

122 Further clarification that a situation of armed conflict is not required for the commission of a crime against humanity is provided for in Article 7(2)(a): "Attack directed against any civilian population" means a course of conduct involving the multiple commission of acts referred to in para. 1 against any civilian population, pursuant to or in furtherance of a State or organizational policy to commit such attack.

${ }^{123}$ Such a claim may neglect the longitudinal aspect of the clerical child abuse scandal; because it has been taking place over many decades, many present-day adults may possess direct experience and hence suffer from the same effect.

${ }_{124}$ Ross v. New Brunswick School District No. 15, I SCR 825 (1996).

125 Ibid., para. 49.

${ }^{126}$ Furthermore, it should be noted that the UN Human Rights Committee accepted "that it was reasonable to anticipate that there was a causal link between the expressions of the author and the 'poisoned school environment' experienced by Jewish children in the School district". Malcolm Ross v. Canada, 18 October 2000, Human Rights Committee, Communication No. 736/1997 (U.N. Doc. CCPR/C/70/D/736/1997).
} 


\section{Hin-Yan Liu}

school. The display of the crucifix on public schoolroom walls should thus be appropriately restricted on similar grounds. Although there is presently no direct evidence of child sex abuse in Italian public schools that is perpetrated by members of the Catholic Church, its disgraceful and systematic activities in other analogous contexts towards the demographic of children may be suffcient to justify its removal in schools generally. The gravity associated with the mantle of international crime only makes its removal more pressing to prevent the possibility of the crucifix as hate speech that is capable of degrading and intimidating children.

\section{CONCLUSION}

Far from being "the universal sign of the acceptance of and respect for every human" as claimed by the Regional Administrative Court in Lautsi, ${ }^{127}$ the preferential treatment of Christian religions in the law and on the international plane provides evidence of religious discrimination. This is magnified by the apparent majoritarian support in Europe that renders imperceptible the potential harm inflicted by those who do not adhere to the faith. Indeed, the discriminatory nature and purpose of religious symbols was accorded inadequate weight in Lautsi. Despite the obvious communicative nature of symbols, the Grand Chamber asserted the diametrically opposite position in concluding that the crucifix is "essentially passive".

Rather than dwell on these objections, those seeking to remove the crucifix from public schoolrooms should instead seek to expand the grounds of objection into the realm of the freedom of speech for it is here that powerful arguments invoking hate speech may be made. The accelerating momentum of the child sexual abuse scandal of the Catholic Church should be utilised to illustrate the particular susceptibility of children to interpret the sign as a form of hate speech that degrades and intimates them. The situation as it currently stands is intolerable: children, a particularly vulnerable demographic, are compelled to spend their day under the ubiquitous gaze of the crucifix-the symbol of the Catholic Church that is alleged to have been, and perhaps continues to be, perpetrating a crime against humanity against them.

127 Judgement No. 1110 of 17 March 2005, para. 13.4., as cited in the Lautsi Grand Chamber Judgement (supra note 1, para. 15). 